\title{
Editorial
}

\section{Eberhard F. Mammen Award Announcements: Part I-Most Popular Articles}

\author{
Emmanuel J. Favaloro, PhD, FFSc (RCPA) ${ }^{1}$ \\ ${ }^{1}$ Department of Haematology, Institute of Clinical Pathology and \\ Medical Research, Westmead Hospital, Westmead, Australia
}

Semin Thromb Hemost 2018;44:185-192.

Welcome to the latest of our Eberhard F Mammen award announcements. As noted previously, ${ }^{1-3}$ Thieme, the publisher of Seminars in Thrombosis \& Hemostasis (STH), has created the Eberhard F Mammen Excellence in Thrombosis and Hemostasis Awards in honor of Eberhard Mammen (- Fig. 1) and in recognition of his contribution to this field and to the journal that he both founded and steered for more than three decades. These awards began in 2009, under two categories, "Most Popular Article Awards" and "Young Investigator Awards." Current details and conditions of the award can be summarized as follows:

- Most Popular Article Awards: These are awarded to the authors of the most popular articles published in STH. The awards are determined by the Editor-in-Chief on the basis of user statistics from Thieme e-Journals for the preceding 2 years. Prefaces, Errata, Letters to the Editor, Editorials, and previous award-winning articles are excluded from

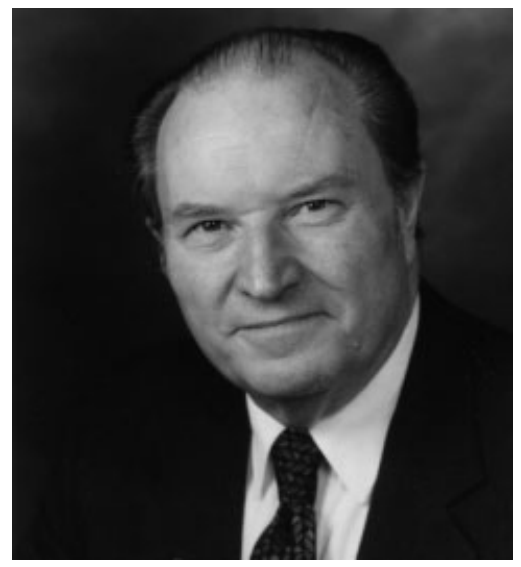

Fig. 1 Eberhard F Mammen (1930-2008).

Address for correspondence E.J. Favaloro, PhD, FFSc (RCPA) Department of Haematology, Institute of Clinical Pathology and Medical Research, Westmead Hospital, Westmead,

New South Wales 2145, Australia (e-mail: emmanuel.

favaloro@health.nsw.gov.au). further consideration of these awards, which currently comprise two categories: one for "Open Access" articles and another for a "General Category." There are two major cash prizes of US\$1,000 for each category. In addition, winners of the "General Category" awards are granted "open access" status for these articles thereafter.

- Young Investigator Awards: These are awarded for the best presentation or meeting abstract by a young investigator, as presented or delivered to an international or large regional meeting on a topic related to the fields of thrombosis and hemostasis, and whose subject matter is determined to be in the spirit of Dr. Mammen. There are up to six cash prizes of US\$1,000 in any year. There are some additional considerations and conditions for the award, and awardees are expected to prepare a review or other paper related to the topic of their presentation for publication in STH.

Further details of the awards and the award winners are posted online (https://www.thieme-connect.com/products/ ejournals/journal/10.1055/s-00000077), and previous award winner announcements are also available in print. ${ }^{4-17}$

It is therefore with great pleasure that we would like to announce the latest winners of the 2018 Eberhard F Mammen awards for the most popular articles from STH for the period of 2016 to 2017 inclusive. We will be announcing the Young Investigator Awards related to meetings held in the recent past at a forthcoming opportunity.

\section{8 "Most Popular" Article Awards}

As mentioned previously, the Most Popular awards are given to the authors of the most popular articles published in STH as determined on the basis of user statistics from the publisher of this journal and covering the preceding 2-year period. Thus, the 2018 "Most Popular" awards are
Copyright (C) 2018 by Thieme Medical Publishers, Inc., 333 Seventh Avenue, New York, NY 10001, USA. Tel: +1(212) 584-4662.
DOI https://doi.org/ 10.1055/s-0038-1637740. ISSN 0094-6176.

\section{Compilation V; Guest Editors:} Emmanuel J. Favaloro, PhD, FFSc
(RCPA), and Giuseppe Lippi, MD. 
granted to the most popular papers from 2016 to 2017 inclusive. Previous Eberhard F Mammen award-winning articles are listed in - Table 1. These articles are currently available under an "Open Access" status and no longer qualify for future awards, although many will continue to appear in the most popular download statistics provided by the publisher. Indeed, not unexpectedly, all previous award-winning articles made the top 150 list, with most ranking highly and still proving popular with our readership.

There is also an increasingly recognized trend to publish articles in an open-access mode, and these have an "inequitable advantage" over other "non-open access" articles in terms of downloads because of their easy accessibility.

Table 1 Previous most popular award-winning papers

\begin{tabular}{|c|c|c|}
\hline Year & Awarded for & $\begin{array}{l}\text { Position in the } \\
2018 \text { list }\end{array}$ \\
\hline 2009 & $\begin{array}{l}\text { Jurk K, Kehrel BE. Platelets: physiology and biochemistry. Semin Thromb Hemost } \\
\text { 2005;31(4):381-392 }\end{array}$ & 4 \\
\hline 2009 & $\begin{array}{l}\text { Girolami B, Girolami A. Heparin-induced thrombocytopenia: a review. Semin } \\
\text { Thromb Hemost 2006;32(8):803-809 }\end{array}$ & 44 \\
\hline 2010 & $\begin{array}{l}\text { Harenberg J, Wehling M. Current and future prospects for anticoagulant therapy: } \\
\text { inhibitors of factor Xa and factor Ila. Semin Thromb Hemost 2008;34(1):39-57 }\end{array}$ & 69 \\
\hline 2010 & $\begin{array}{l}\text { Prechel M, Walenga JM. The laboratory diagnosis and clinical management of } \\
\text { patients with heparin-induced thrombocytopenia: an update. Semin Thromb } \\
\text { Hemost 2008;34(1):86-96 }\end{array}$ & 43 \\
\hline 2010 & $\begin{array}{l}\text { Fareed J, Hoppensteadt DA, Fareed D, Demir M, Wahi R, Clarke M, Adiguzel C, Bick } \\
\text { R. Survival of heparins, oral anticoagulants, and aspirin after the year } 2010 \text {. Semin } \\
\text { Thromb Hemost } 2008 ; 34(1): 58-73\end{array}$ & 36 \\
\hline 2011 & $\begin{array}{l}\text { Sobieraj-Teague M, O'Donnell M, Eikelboom J. New anticoagulants for atrial } \\
\text { fibrillation. Semin Thromb Hemost 2009;35(5):515-524 }\end{array}$ & 56 \\
\hline 2011 & $\begin{array}{l}\text { Mariani G, Bernardi F. Factor VII Deficiency. Semin Thromb Hemost 2009;35 } \\
\text { (4):400-406 }\end{array}$ & 8 \\
\hline 2012 & $\begin{array}{l}\text { Lippi G, Franchini M, Favaloro EJ, Targher G. Moderate red wine consumption and } \\
\text { cardiovascular disease risk: beyond the "French paradox." Semin Thromb Hemost } \\
\text { 2010;36(1):59-70 }\end{array}$ & 3 \\
\hline 2012 & Rak J. Microparticles in cancer. Semin Thromb Hemost 2010;36(8):888-906 & 9 \\
\hline 2013 & $\begin{array}{l}\text { Fava C, Montagnana M, Favaloro EJ, Guidi GC, Lippi G. Obstructive sleep apnea } \\
\text { syndrome and cardiovascular diseases. Semin Thromb Hemost 2011;37(3):280-297 }\end{array}$ & 24 \\
\hline 2013 & $\begin{array}{l}\text { Tufano A, Guida A, Dario Di Minno MN, Prisco D, Cerbone AM, Minno GD. } \\
\text { Prevention of venous thromboembolism in medical patients with thrombocyto- } \\
\text { penia or with platelet dysfunction: a review of the literature. Semin Thromb } \\
\text { Hemost } 2011 ; 37(3): 267-274\end{array}$ & 7 \\
\hline 2014 & $\begin{array}{l}\text { Salmela B, Joutsi-Korhonen L, Armstrong E, Lassila R. Active online assessment of } \\
\text { patients using new oral anticoagulants: bleeding risk, compliance, and coagula- } \\
\text { tion analysis. Semin Thromb Hemost 2012;38(1):23-30 }\end{array}$ & 45 \\
\hline 2014 & $\begin{array}{l}\text { Chapman K, Seldon M, Richards R. Thrombotic microangiopathies, thrombotic } \\
\text { thrombocytopenic purpura, and ADAMTS-13. Semin Thromb Hemost 2012;38 } \\
\text { (1):47-54 }\end{array}$ & 10 \\
\hline 2014 & $\begin{array}{l}\text { Kenet G, Aronis S, Berkun Y, Bonduel M, Chan A, Goldenberg NA, Holzhauer S, Iorio } \\
\text { A, Journeycake J, Junker R, Male C, Manco-Johnson M, Massicotte P, Mesters R, } \\
\text { Monagle P, van Ommen H, Rafini L, Simioni P, Young G, Nowak-Göttl U. Impact of } \\
\text { persistent antiphospholipid antibodies on risk of incident symptomatic throm- } \\
\text { boembolism in children: a systematic review and meta-analysis. Semin Thromb } \\
\text { Hemost 2011;37(7):802-809 }\end{array}$ & 14 \\
\hline 2015 & $\begin{array}{l}\text { Tapson VF. Thrombolytic therapy for acute pulmonary embolism. Semin Thromb } \\
\text { Hemost 2013;39(4):452-458 }\end{array}$ & 35 \\
\hline 2015 & $\begin{array}{l}\text { George JN, Charania RS. Evaluation of patients with microangiopathic hemolytic } \\
\text { anemia and thrombocytopenia. Semin Thromb Hemost 2013;39(2):153-160 }\end{array}$ & 6 \\
\hline $2015^{a}$ & $\begin{array}{l}\text { Hylek EM. Anticoagulation therapy for atrial fibrillation. Semin Thromb Hemost } \\
2013 ; 39(2): 147-152\end{array}$ & 48 \\
\hline $2015^{a}$ & $\begin{array}{l}\text { Rojas-Hernandez CM, Garcia DA. The novel oral anticoagulants. Semin Thromb } \\
\text { Hemost 2013;39(2):117-126 }\end{array}$ & 138 \\
\hline
\end{tabular}


Table 1 (Continued)

\begin{tabular}{|c|c|c|}
\hline Year & Awarded for & $\begin{array}{l}\text { Position in the } \\
2018 \text { list }\end{array}$ \\
\hline 2016 & $\begin{array}{l}\text { de Moerloose P, Casini A, Neerman-Arbez M. Congenital fibrinogen disorders: an } \\
\text { update. Semin Thromb Hemost 2013;39(6):585-595 }\end{array}$ & 13 \\
\hline 2016 & $\begin{array}{l}\text { Sethi S, Fervenza FC. Pathology of renal diseases associated with dysfunction of } \\
\text { the alternative pathway of complement: C3 glomerulopathy and atypical hemo- } \\
\text { lytic uremic syndrome (aHUS). Semin Thromb Hemost 2014;40(4):416-421 }\end{array}$ & 20 \\
\hline $2016^{a}$ & $\begin{array}{l}\text { Bates SM. D-dimer assays in diagnosis and management of thrombotic and } \\
\text { bleeding disorders. Semin Thromb Hemost 2012;38(7):673-682 }\end{array}$ & 26 \\
\hline $2016^{a}$ & $\begin{array}{l}\text { Lippi G, Favaloro EJ, Meschi T, Mattiuzzi C, Borghi L, Cervellin G. E-cigarettes and } \\
\text { cardiovascular risk: beyond science and mysticism. Semin Thromb Hemost } \\
\text { 2014;40(1):60-65 }\end{array}$ & 2 \\
\hline 2017 & $\begin{array}{l}\text { Boonyawat K, Crowther MA. Venous thromboembolism prophylaxis in critically ill } \\
\text { patients. Semin Thromb Hemost 2015;41(1):68-74 }\end{array}$ & 62 \\
\hline 2017 & $\begin{array}{l}\text { Levi M, Poll TV. Coagulation in Patients with Severe Sepsis. Semin Thromb Hemost } \\
\text { 2015;41(1):9-15 }\end{array}$ & 75 \\
\hline $2017^{a}$ & $\begin{array}{l}\text { Moore GW. Recent guidelines and recommendations for laboratory detection of } \\
\text { lupus anticoagulants. Semin Thromb Hemost 2014;40(2):163-171 }\end{array}$ & 1 \\
\hline $2017^{a}$ & $\begin{array}{l}\text { Warkentin TE. Heparin-induced thrombocytopenia in critically ill patients. Semin } \\
\text { Thromb Hemost } 2015 ; 41(1): 49-60\end{array}$ & 11 \\
\hline $2017^{b}$ & $\begin{array}{l}\text { Favaloro EJ, Lippi G. Laboratory testing in the era of direct or non-vitamin K } \\
\text { antagonist oral anticoagulants: a practical guide to measuring their activity and } \\
\text { avoiding diagnostic errors. Semin Thromb Hemost } 2015 ; 41(2): 208-227\end{array}$ & 5 \\
\hline
\end{tabular}

${ }^{a}$ New Open Access category.

bThis paper qualified as the "Most Popular" award winner based on objective publisher provided download data; however, as this paper was written by the journal Editor-in-Chief, there was an obvious conflict of interest, and the award was officially declined. This paper is listed here merely as a statement of record.

Accordingly, the publisher of STH has established a separate category of the Most Popular Award for "open-access" papers, to supplement the alternate "General Category," and thus the most popular papers are now listed in separate tables. - Table 2 lists the top 20 downloaded open-access articles from STH (2016 and 2017 inclusive), as eligible for the "Open Access" award. ${ }^{18-37}$-Table 3 lists the top 20 downloaded non-open access articles from STH (2016 and 2017 inclusive), as otherwise eligible for the "General Category" award. ${ }^{38-57}$

Accordingly, the 2017 Eberhard F Mammen award winners for the most popular article (2016 and 2017 inclusive) are as follows:

- Open Access Category: $:^{18,19}$

- Cuker A, Prak ET, Cines DB. Can immune thrombocytopenia be cured with medical therapy? Semin Thromb Hemost 2015;41(4):395-404.

- Cuker A. Clinical and laboratory diagnosis of heparininduced thrombocytopenia: an integrated approach. Semin Thromb Hemost 2014;40(1):106-114.

- General Category: ${ }^{38,39}$

- Gremmel T, Frelinger AL 3rd, Michelson AD. Platelet physiology. Semin Thromb Hemost 2016;42(3):191204.

- Mallett SV. Clinical utility of viscoelastic tests of coagulation (TEG/ROTEM) in patients with liver disease and during liver transplantation. Semin Thromb Hemost 2015;41(5):527-537.

It is always interesting to me how some issues, in particular, seem to catch the attention of the readership. The topranking issues this round from the aspect of having four or more papers in the top 100 download list were: Hot Topics V, ${ }^{58}$ Anticoagulant Therapy: Present and Future, ${ }^{59}$ Editorial Compilation I, ${ }^{60}$ Platelet Function in Thrombosis and Hemostasis, ${ }^{61}$ and Controversies in Inherited Bleeding Disorders. $^{62}$

All authors of the award-winning articles were thrilled to hear that their papers had won an Eberhard F Mammen Most Popular award, and provided the following additional responses:

From Dr. Adam Cuker (-Fig. 2): "On behalf of my coauthors, I am truly humbled and delighted to receive not one but two Eberhard Mammen 2018 Most Popular Article Awards. As with novelists, poets, and playwrights, we in the biomedical community write in the hopes of reaching and illuminating our audience and perhaps of moving the needle in our chosen field, if ever-so-slightly, in the direction of progress. These awards are a vindication of our work. I am deeply grateful to Seminars in Thrombosis and Hemostasis and to its founding Editor-in-Chief, Eberhard Mammen, for providing a platform for me to reach my audience." One of 
Table 2 Most popular papers: "Open Access" category ${ }^{a}$

\begin{tabular}{|c|c|}
\hline Rank & Publication \\
\hline 1 & $\begin{array}{l}\text { Cuker A, Prak ET, Cines DB. Can immune thrombocytopenia be cured with medical therapy? Semin Thromb } \\
\text { Hemost } 2015 ; 41(4): 395-404\end{array}$ \\
\hline 2 & $\begin{array}{l}\text { Cuker A. Clinical and laboratory diagnosis of heparin-induced thrombocytopenia: an integrated approach. Semin } \\
\text { Thromb Hemost 2014;40(1):106-114 }\end{array}$ \\
\hline 3 & Schulman S. Update on the treatment of venous thromboembolism. Semin Thromb Hemost 2016;42(8):891-898 \\
\hline 4 & $\begin{array}{l}\text { Raskob GE, Angchaisuksiri P, Blanco AN, Büller H, Gallus A, Hunt BJ, Hylek EM, Kakkar TL, Konstantinides SV, } \\
\text { McCumber M, Ozaki Y, Wendelboe A, Weitz JI; ISTH Steering Committee for World Thrombosis Day. Thrombosis: } \\
\text { a major contributor to global disease burden. Semin Thromb Hemost 2014;40(7):724-735 }\end{array}$ \\
\hline 5 & $\begin{array}{l}\text { Elewa H, Ahmed D, Barnes GD. Triple oral antithrombotic therapy in atrial fibrillation and coronary artery } \\
\text { stenting: searching for the best combination. Semin Thromb Hemost 2016;42(6):662-670 }\end{array}$ \\
\hline 6 & Althaus K, Greinacher A. MYH9-related platelet disorders. Semin Thromb Hemost 2009;35(2):189-203 \\
\hline 7 & $\begin{array}{l}\text { Tersteeg C, Fijnheer R, Pasterkamp G, de Groot PG, Vanhoorelbeke K, de Maat S, Maas C. Keeping von Willebrand } \\
\text { factor under control: alternatives for ADAMTS13. Semin Thromb Hemost 2016;42(1):9-17 }\end{array}$ \\
\hline 8 & Favaloro EJ. Clinical utility of the PFA-100. Semin Thromb Hemost 2008;34(8):709-733 \\
\hline 9 & $\begin{array}{l}\text { Demers M, Wagner DD. NETosis: a new factor in tumor progression and cancer-associated thrombosis. Semin } \\
\text { Thromb Hemost 2014;40(3):277-283 }\end{array}$ \\
\hline 10 & $\begin{array}{l}\text { Mannucci PM, Mancuso ME, Santagostino E, Franchini M. Innovative pharmacological therapies for the } \\
\text { hemophilias not based on deficient factor replacement. Semin Thromb Hemost 2016;42(5):526-532 }\end{array}$ \\
\hline 11 & Nurden AT. Platelet membrane glycoproteins: a historical review. Semin Thromb Hemost 2014;40(5):577-584 \\
\hline 12 & $\begin{array}{l}\text { Wada H, Usui M, Sakuragawa N. Hemostatic abnormalities and liver diseases. Semin Thromb Hemost 2008;34 } \\
\text { (8):772-778 }\end{array}$ \\
\hline 13 & $\begin{array}{l}\text { Harenberg J, Du S, Krämer S, Weiss C, Krämer R, Wehling M. Patients' serum and urine as easily accessible samples for } \\
\text { the measurement of non-vitamin K antagonist oral anticoagulants. Semin Thromb Hemost 2015;41(2):228-236 }\end{array}$ \\
\hline 14 & Italiano JE Jr. Unraveling mechanisms that control platelet production. Semin Thromb Hemost 2013;39(1):15-24 \\
\hline 15 & Mammen EF. Sticky platelet syndrome. Semin Thromb Hemost 1999;25(4):361-365 \\
\hline 16 & $\begin{array}{l}\text { Zolfaghari S, Harenberg J, Frölich L, Weiss C, Wehling M, Wild P, Prochaska J, Beyer-Westendorf J, Koscielny J, Lip } \\
\text { GY. Development of recommendations to continue anticoagulation with one of the two types of oral antic- } \\
\text { oagulants based on the identification of patients' preference. Semin Thromb Hemost 2015;41(2):166-177 }\end{array}$ \\
\hline 17 & $\begin{array}{l}\text { Chighizola CB, Raimondo MG, Meroni PL. Management of thrombotic antiphospholipid syndrome. Semin Thromb } \\
\text { Hemost 2017. doi: 10.1055/s-0036-1597282. [e-pub ahead of print] PubMed PMID: } 28278524\end{array}$ \\
\hline 18 & $\begin{array}{l}\text { Harenberg J, Kraemer S, Du S, Giese C, Schulze A, Kraemer R, Weiss C. Determination of direct oral anticoagulants } \\
\text { from human serum samples. Semin Thromb Hemost 2014;40(1):129-134 }\end{array}$ \\
\hline 19 & $\begin{array}{l}\text { Favaloro EJ, Pasalic L, Curnow J. Type 2M and type 2A von Willebrand disease: similar but different. Semin Thromb } \\
\text { Hemost 2016;42(5):483-497 }\end{array}$ \\
\hline 20 & $\begin{array}{l}\text { Zolfaghari S, Harenberg J, Froelich L, Wehling M, Weiss C. Development of a tool to identify patients' preference } \\
\text { for vitamin K antagonist or direct oral anticoagulant therapy. Semin Thromb Hemost 2014;440(1):121-128 }\end{array}$ \\
\hline
\end{tabular}

a2016 and 2017 inclusive; excludes nonqualifying material (e.g., Prefaces, Errata, Letters to the Editor, Editorials, and previous award-winning articles).

Dr. Cuker's coauthors, Dr. Eline T Luning Prak, also provided a portrait photo for use in the editorial (-Fig. 3), but Dr. Douglas B. Cines declined to do so.

From Dr. Thomas Gremmel (-Fig. 4): "I am grateful and truly honored to receive an Eberhard F. Mammen Most Popular Article Award in 2018 as it reflects the great interest in our work. It is amazing that our review on Platelet Physiology has already attracted a lot of attention within the scientific community, and was read and cited by many distinguished colleagues. I would like to thank my coauthors Alan D. Michelson and Andrew L. Frelinger for their support in preparing the article, Anne-Mette Hvas for her invitation to contribute a review article, and the publisher for providing the award. The editors of Seminars in Thrombosis and Hemos- tasis have to be complimented on their continued selection of very relevant topics for respective issues of the Journal. As a source of excellent review articles in thrombosis and hemostasis research, this journal plays a pivotal role in the dissemination of knowledge in the field. In this regard, I am particularly pleased that our article will now be given a 'free access' status, which will foster its further distribution." Both of Dr. Gremmel's coauthors, Drs. Andrew L. Frelinger III and Alan D. Michelson, also provided portrait photos for use in this editorial (-Figs. 5 and $\mathbf{6}$ ).

From Dr. Susan Mallett (-Fig. 7): "I was both delighted and surprised to receive the news that my review article had won a 2018 Eberhard Mammen award for the 'general' category. It is indeed a great honor, and highlights 
Table 3 Most popular papers: "General” category"

\begin{tabular}{|c|c|}
\hline Rank & Publication \\
\hline 1 & Gremmel T, Frelinger AL 3rd, Michelson AD. Platelet physiology. Semin Thromb Hemost 2016;42(3):191-204 \\
\hline 2 & $\begin{array}{l}\text { Mallett SV. Clinical utility of viscoelastic tests of coagulation (TEG/ROTEM) in patients with liver disease and } \\
\text { during liver transplantation. Semin Thromb Hemost 2015;41(5):527-537 }\end{array}$ \\
\hline 3 & $\begin{array}{l}\text { Kumar R, Dunn A, Carcao M. Changing paradigm of hemophilia management: extended half-life factor } \\
\text { concentrates and gene therapy. Semin Thromb Hemost 2016;42(1):18-29 }\end{array}$ \\
\hline 4 & $\begin{array}{l}\text { Gando S, Hayakawa M. Pathophysiology of trauma-induced coagulopathy and management of critical bleeding } \\
\text { requiring massive transfusion. Semin Thromb Hemost 2016;42(2):155-165 }\end{array}$ \\
\hline 5 & $\begin{array}{l}\text { Boccardo P, Remuzzi G, Galbusera M. Platelet dysfunction in renal failure. Semin Thromb Hemost 2004;30 } \\
\text { (5):579-589 }\end{array}$ \\
\hline 6 & Lassila R. Platelet function tests in bleeding disorders. Semin Thromb Hemost 2016;42(3):185-190 \\
\hline 7 & $\begin{array}{l}\text { Franchini M, Mengoli C, Capuzzo E, Terenziani I, Bonfanti C, Lippi G. Correlation between ABO blood group, and } \\
\text { conventional hematological and metabolic parameters in blood donors. Semin Thromb Hemost 2016;42(1):75-86 }\end{array}$ \\
\hline 8 & $\begin{array}{l}\text { McEwen BJ, Morel-Kopp MC, Tofler GH, Ward CM. The effect of omega-3 polyunsaturated fatty acids on fibrin and } \\
\text { thrombin generation in healthy subjects and subjects with cardiovascular disease. Semin Thromb Hemost } \\
2015 ; 41(3): 315-322\end{array}$ \\
\hline 9 & Schreiber K, Hunt BJ. Pregnancy and antiphospholipid syndrome. Semin Thromb Hemost 2016;42(7):780-788 \\
\hline 10 & $\begin{array}{l}\text { Semeraro N, Ammollo CT, Semeraro F, Colucci M. Coagulopathy of acute sepsis. Semin Thromb Hemost 2015;41 } \\
\text { (6):650-658 }\end{array}$ \\
\hline 11 & Lordkipanidzé M. Platelet function tests. Semin Thromb Hemost 2016;42(3):258-267 \\
\hline 12 & Baskurt OK, Meiselman HJ. Blood rheology and hemodynamics. Semin Thromb Hemost 2003;29(5):435-450 \\
\hline 13 & $\begin{array}{l}\text { Scully M. Thrombotic thrombocytopenic purpura and atypical hemolytic uremic syndrome microangiopathy in } \\
\text { pregnancy. Semin Thromb Hemost 2016;42(7):774-779 }\end{array}$ \\
\hline 14 & Curnow J, Pasalic L, Favaloro EJ. Treatment of von Willebrand disease. Semin Thromb Hemost 2016;42(2):133-146 \\
\hline 15 & $\begin{array}{l}\text { Reynen E, James P. Von Willebrand disease and pregnancy: a review of evidence and expert opinion. Semin } \\
\text { Thromb Hemost 2016;42(7):717-723 }\end{array}$ \\
\hline 16 & $\begin{array}{l}\text { Riva N, Dentali F, Permunian ET, Ageno W. Major bleeding and case fatality rate with the direct oral anticoagulants } \\
\text { in orthopedic surgery: a systematic review and meta-analysis. Semin Thromb Hemost 2016;42(1):42-54 }\end{array}$ \\
\hline 17 & $\begin{array}{l}\text { Ramström S, Södergren AL, Tynngård N, Lindahl TL. Platelet function determined by flow cytometry: new } \\
\text { perspectives? Semin Thromb Hemost 2016;42(3):268-281 }\end{array}$ \\
\hline 18 & Scharf RE. Drugs that affect platelet function. Semin Thromb Hemost 2012;38(8):865-883 \\
\hline 19 & $\begin{array}{l}\text { Franchini M, Coppola A, Tagliaferri A, Lippi G. FEIBA versus NovoSeven in hemophilia patients with inhibitors. } \\
\text { Semin Thromb Hemost 2013;39(7):772-778 }\end{array}$ \\
\hline 20 & $\begin{array}{l}\text { Senoo K, Lip GY. Comparative efficacy and safety of the non-vitamin K antagonist oral anticoagulants for patients } \\
\text { with nonvalvular atrial fibrillation. Semin Thromb Hemost } 2015 ; 41(2): 146-153\end{array}$ \\
\hline
\end{tabular}

a2016 and 2017 inclusive; excludes nonqualifying material (e.g., Prefaces, Errata, Letters to the Editor, Editorials, and previous award-winning articles).

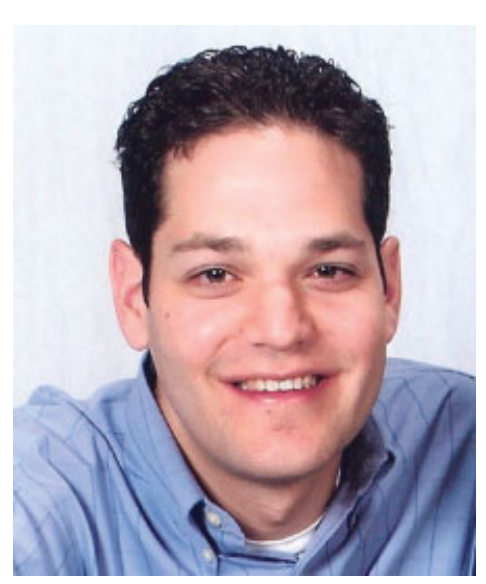

Fig. 2 Dr. Adam Cuker.

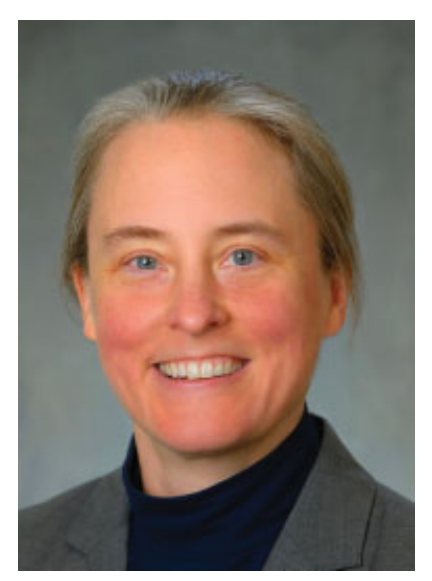

Fig. 3 Dr. Eline T. Luning Prak. 


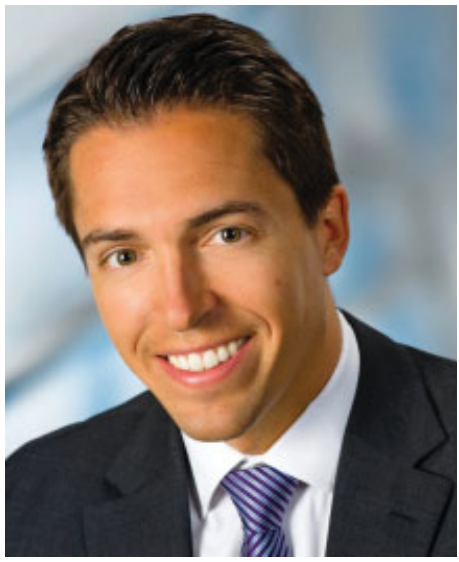

Fig. 4 Dr. Thomas Gremmel.

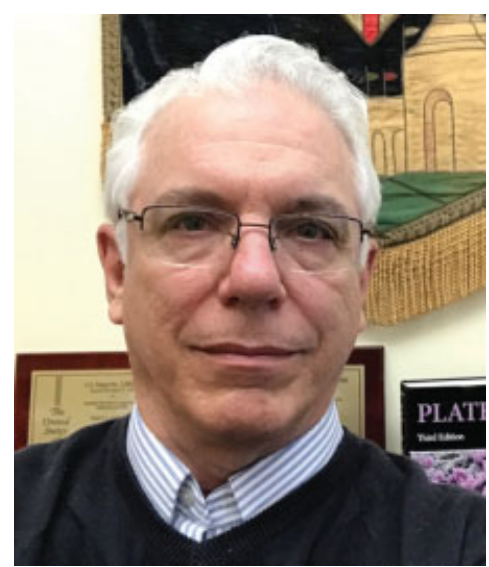

Fig. 5 Dr. Andrew L. Frelinger III.

the degree of interest this article has attracted within the scientific community. It is especially valuable to me personally; as for so many years, outside of the field of perioperative medicine in which I practice; there has only been limited interest in the enormous potential of viscoelastic tests to provide clinically relevant and individualized information about the hemostatic status. Over the last decade, there has been a paradigm shift in the way coagulation in liver disease

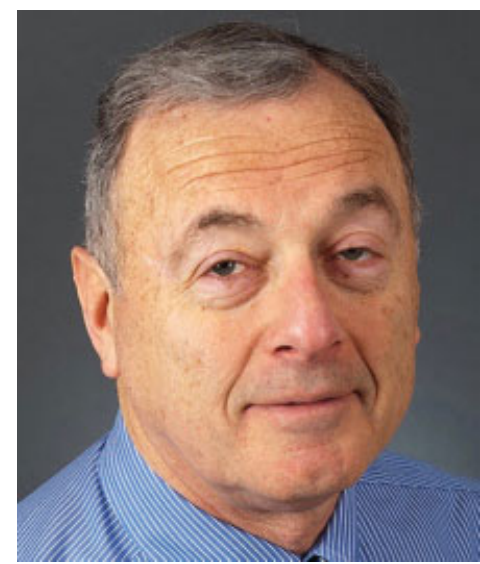

Fig. 6 Dr. Alan D. Michelson.

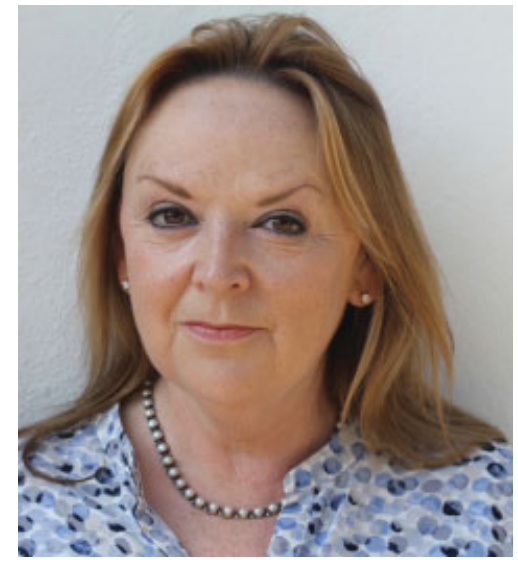

Fig. 7 Dr. Susan Mallett.

is understood, with much new and exciting work demonstrating that hemostasis is finely, albeit precariously, 'rebalanced' in stable patients with liver disease due to the multiple and complex changes that occur in the hemostatic system. The many limitations and inadequacies of conventional coagulation tests in terms of assessing bleeding and thrombotic risk in patients with liver disease are now recognized. Future research using global viscoelastic tests will undoubtedly help elucidate some of these risks, and also give more relevant information that has the potential to eliminate many precautionary component transfusions that are completely unnecessary. As a consequence, clinical practice may be significantly altered for the better. I would very much like to thank Professors Ton Lisman and Hau Kwaan, who guest edited the issue on Hemostatic Dysfunction in Liver Diseases, for having given me the opportunity to write this review article for STH."

I must admit to particular joy on this occasion with these announcements. For example, Dr. Cuker won both awards for the "Open Access" Category. This is a first-time event in the history of these awards-to have one author win two of the available awards. Dr. Cuker is a member of the STH editorial board, having been invited to join soon after he won an earlier (2010) STH Young Investigator Award. Dr. Cuker has contributed several papers to STH, typically well received by our readership, and most recently undertook a guest editor role for an issue of STH, shepherding an issue on Clinical Scoring Systems in Thrombosis and Hemostasis for the journal. ${ }^{63}$

Also interesting is that the issue on platelets ${ }^{61}$ was very popular, a finding that may have been predicted by the ongoing presence of one paper from 2005, ${ }^{31}$ a 2009 Most Popular Award winner (-Table 1), on every annual Most Popular Award announcements. ${ }^{4,6-10,12,14,15}$ I was also very proud to see two giants in the field, Drs. Larry Frelinger and Alan Michelson, share in a win on this occasion. ${ }^{38}$

Finally, I was particularly proud to see Eberhard F Mammen himself appear on the listing (-Table 2, number 15), for a paper he wrote on "sticky platelet syndrome" and published in $1999 .^{64}$ This renewed interest in "sticky platelet syndrome," one of Eberhard's greatest interests, may have 
been spurred by our recent 40th Anniversary celebration of STH publishing, ${ }^{65,66}$ as well as more recent papers on the topic, ${ }^{67-69}$ in part in tribute to Dr. Mammen.

I would, as always, like to thank not only all of the authors listed in the tables, but also the contributing authors who did not manage to make these listings, as well as all the guest editors of issues recently published in STH. I also look forward to seeing future listings-always a great delight and sometimes quite a surprise.

\section{References}

1 Favaloro EJ. Welcome to a Special Issue of Seminars in Thrombosis and Hemostasis-The Closing Issue for 2008 [Editorial]. Semin Thromb Hemost 2008;34:693-696

2 Favaloro EJ. A tribute to Eberhard F. Mammen, M.D. (1930-2008). Semin Thromb Hemost 2008;34(08):703-707

3 Favaloro EJ. Welcome to the first issue of Seminars in Thrombosis and Hemostasis for 2009 [Editorial]. Semin Thromb Hemost 2009; $35: 1-2$

4 Favaloro EJ. Winners of the Inaugural Eberhard F. Mammen Award for Most Popular Article [Editorial]. Semin Thromb Hemost 2009; 35:587-590

5 Favaloro EJ. 2009 Eberhard F. Mammen Young Investigator Award Winners [Editorial]. Semin Thromb Hemost 2010; 36:469-470

6 Favaloro EJ. Winners of the 2010 Eberhard F. Mammen award for most popular article during 2008-2009. Semin Thromb Hemost 2010;36(07):685-692

7 Favaloro EJ. 2011 Eberhard F. Mammen award announcements. Semin Thromb Hemost 2011;37(05):431-439

8 Favaloro EJ. 2012 Eberhard F. Mammen award announcements. Semin Thromb Hemost 2012;38:425-432

9 Favaloro EJ. 2013 Eberhard F. Mammen award announcements. Semin Thromb Hemost 2013;39:567-574

10 Favaloro EJ. 2014 Eberhard F. Mammen award announcements: Part I - most popular articles. Semin Thromb Hemost 2014;40 (04):407-412

11 Favaloro EJ. 2014 Eberhard F. Mammen award announcements: part II-Young Investigator Awards. Semin Thromb Hemost 2014; 40(07):718-723

12 Favaloro EJ. 2015 Eberhard F. Mammen Award Announcements: Part I-Most Popular Articles. Semin Thromb Hemost 2015;41 (07):673-679

13 Favaloro EJ. 2015 Eberhard F. Mammen Award announcements: part II-Young Investigator Awards. Semin Thromb Hemost 2015; 41(08):809-815

14 Favaloro EJ. 2016 Eberhard F. Mammen Award Announcements: Part I - Most Popular Articles. Semin Thromb Hemost 2016;42 (04):325-330

15 Favaloro EJ. 2016 Eberhard F. Mammen Award Announcements: Part II-Young Investigator Awards. Semin Thromb Hemost 2017; 43(03):235-241

16 Favaloro EJ. 2017 Eberhard F. Mammen Award Announcements: Part I-Most Popular Articles. Semin Thromb Hemost 2017;43(04): 357-363

17 Cuker A, Prak ET, Cines DB. Can immune thrombocytopenia be cured with medical therapy? Semin Thromb Hemost 2015;41 (04):395-404

18 Cuker A. Clinical and laboratory diagnosis of heparin-induced thrombocytopenia: an integrated approach. Semin Thromb Hemost 2014;40(01):106-114

19 Schulman S. Update on the treatment of venous thromboembolism. Semin Thromb Hemost 2016;42(08):891-898

20 Raskob GE, Angchaisuksiri P, Blanco AN, et al; ISTH Steering Committee for World Thrombosis Day. Thrombosis: a major contributor to global disease burden. Semin Thromb Hemost 2014;40(07):724-735

21 Elewa H, Ahmed D, Barnes GD. Triple oral antithrombotic therapy in atrial fibrillation and coronary artery stenting: searching for the best combination. Semin Thromb Hemost 2016;42(06): 662-670

22 Althaus K, Greinacher A. MYH9-related platelet disorders. Semin Thromb Hemost 2009;35(02):189-203

23 Tersteeg C, Fijnheer R, Pasterkamp G, et al. Keeping von Willebrand factor under control: alternatives for ADAMTS13. Semin Thromb Hemost 2016;42(01):9-17

24 Favaloro EJ. Clinical utility of the PFA-100. Semin Thromb Hemost 2008;34(08):709-733

25 Demers M, Wagner DD. NETosis: a new factor in tumor progression and cancer-associated thrombosis. Semin Thromb Hemost 2014;40(03):277-283

26 Mannucci PM, Mancuso ME, Santagostino E, Franchini M. Innovative pharmacological therapies for the hemophilias not based on deficient factor replacement. Semin Thromb Hemost 2016;42 (05):526-532

27 Nurden AT. Platelet membrane glycoproteins: a historical review. Semin Thromb Hemost 2014;40(05):577-584

28 Wada H, Usui M, Sakuragawa N. Hemostatic abnormalities and liver diseases. Semin Thromb Hemost 2008;34(08):772778

29 Harenberg J, Du S, Krämer S, Weiss C, Krämer R, Wehling M. Patients' serum and urine as easily accessible samples for the measurement of non-vitamin $\mathrm{K}$ antagonist oral anticoagulants. Semin Thromb Hemost 2015;41(02):228-236

30 Italiano JE Jr. Unraveling mechanisms that control platelet production. Semin Thromb Hemost 2013;39(01):15-24

31 Mammen EF. Sticky platelet syndrome. Semin Thromb Hemost 1999;25(04):361-365

32 Zolfaghari S, Harenberg J, Frölich L, et al. Development of recommendations to continue anticoagulation with one of the two types of oral anticoagulants based on the identification of patients' preference. Semin Thromb Hemost 2015;41(02): 166-177

33 Chighizola CB, Raimondo MG, Meroni PL. Management of thrombotic antiphospholipid syndrome. Semin Thromb Hemost 2017 (e-pub ahead of print) . Doi: 10.1055/s-0036-1597282

34 Harenberg J, Kraemer S, Du S, et al. Determination of direct oral anticoagulants from human serum samples. Semin Thromb Hemost 2014;40(01):129-134

35 Favaloro EJ, Pasalic L, Curnow J. Type 2M and type 2A von Willebrand disease: similar but different. Semin Thromb Hemost 2016;42(05):483-497

36 Zolfaghari S, Harenberg J, Froelich L, Wehling M, Weiss C. Development of a tool to identify patients' preference for vitamin $\mathrm{K}$ antagonist or direct oral anticoagulant therapy. Semin Thromb Hemost 2014;40(01):121-128

37 Gremmel T, Frelinger AL III, Michelson AD. Platelet physiology. Semin Thromb Hemost 2016;42(03):191-204

38 Mallett SV. Clinical utility of viscoelastic tests of coagulation (TEG/ROTEM) in Patients with liver disease and during liver transplantation. Semin Thromb Hemost 2015;41(05):527537

39 Kumar R, Dunn A, Carcao M. Changing paradigm of hemophilia management: extended half-life factor concentrates and gene therapy. Semin Thromb Hemost 2016;42(01):18-29

40 Gando S, Hayakawa M. Pathophysiology of trauma-induced coagulopathy and management of critical bleeding requiring massive transfusion. Semin Thromb Hemost 2016;42(02): 155-165

41 Boccardo P, Remuzzi G, Galbusera M. Platelet dysfunction in renal failure. Semin Thromb Hemost 2004;30(05):579-589

42 Lassila R. Platelet function tests in bleeding disorders. Semin Thromb Hemost 2016;42(03):185-190 
43 Franchini M, Mengoli C, Capuzzo E, Terenziani I, Bonfanti C, Lippi G. Correlation between $\mathrm{ABO}$ blood group, and conventional hematological and metabolic parameters in blood donors. Semin Thromb Hemost 2016;42(01):75-86

44 McEwen BJ, Morel-Kopp MC, Tofler GH, Ward CM. The effect of omega-3 polyunsaturated fatty acids on fibrin and thrombin generation in healthy subjects and subjects with cardiovascular disease. Semin Thromb Hemost 2015;41(03):315-322

45 Schreiber K, Hunt BJ. Pregnancy and antiphospholipid syndrome. Semin Thromb Hemost 2016;42(07):780-788

46 Semeraro N, Ammollo CT, Semeraro F, Colucci M. Coagulopathy of acute sepsis. Semin Thromb Hemost 2015;41(06):650-658

47 Lordkipanidzé M. Platelet function tests. Semin Thromb Hemost 2016;42(03):258-267

48 Baskurt OK, Meiselman HJ. Blood rheology and hemodynamics. Semin Thromb Hemost 2003;29(05):435-450

49 Scully M. Thrombotic thrombocytopenic purpura and atypical hemolytic uremic syndrome microangiopathy in pregnancy. Semin Thromb Hemost 2016;42(07):774-779

50 Curnow J, Pasalic L, Favaloro EJ. Treatment of von Willebrand disease. Semin Thromb Hemost 2016;42(02):133-146

51 Reynen E, James P. Von Willebrand disease and pregnancy: a review of evidence and expert opinion. Semin Thromb Hemost 2016;42(07):717-723

52 Riva N, Dentali F, Permunian ET, Ageno W. Major bleeding and case fatality rate with the direct oral anticoagulants in orthopedic surgery: a systematic review and meta-analysis. Semin Thromb Hemost 2016;42(01):42-54

53 Ramström S, Södergren AL, Tynngård N, Lindahl TL. Platelet function determined by flow cytometry: new perspectives? Semin Thromb Hemost 2016;42(03):268-281

54 Scharf RE. Drugs that affect platelet function. Semin Thromb Hemost 2012;38(08):865-883

55 Franchini M, Coppola A, Tagliaferri A, Lippi G. FEIBA versus NovoSeven in hemophilia patients with inhibitors. Semin Thromb Hemost 2013;39(07):772-778
56 Senoo K, Lip GY. Comparative efficacy and safety of the nonvitamin $\mathrm{K}$ antagonist oral anticoagulants for patients with nonvalvular atrial fibrillation. Semin Thromb Hemost 2015;41(02): 146-153

57 Favaloro EJ. Hot topics V. Semin Thromb Hemost 2014;40(01): 5-10

58 Favaloro EJ. Anticoagulant therapy: present and future. Semin Thromb Hemost 2015;41(02):109-112

59 Favaloro EJ, Lippi G. Editorial compilation I. Semin Thromb Hemost 2016;42(01):5-8

60 Hvas AM. Platelet function in thrombosis and hemostasis. Semin Thromb Hemost 2016;42(03):183-184

61 Coppola A, Tagliaferri A, Franchini M. Controversies in inherited bleeding disorders. Semin Thromb Hemost 2016;42(05):459-462

62 Cuker A. Clinical scoring systems in thrombosis and hemostasis. Semin Thromb Hemost 2017;43(05):447-448

63 Jurk K, Kehrel BE. Platelets: physiology and biochemistry. Semin Thromb Hemost 2005;31(04):381-392

64 Favaloro EJ. A short history of Thrombosis and Hemostasis: part I (40th year celebratory issue). Semin Thromb Hemost 2014;40 (05):521-525

65 Favaloro EJ. A short history of thrombosis and hemostasis: part II (40th year celebratory issue). Semin Thromb Hemost 2014;40 (08):826-830

66 Kubisz P, Stasko J, Holly P. Sticky platelet syndrome. Semin Thromb Hemost 2013;39(06):674-683

67 Kubisz P, Ruiz-Argüelles GJ, Stasko J, Holly P, Ruiz-Delgado GJ. Sticky platelet syndrome: history and future perspectives. Semin Thromb Hemost 2014;40(05):526-534

68 Sokol J, Biringer K, Skerenova M, Stasko J, Kubisz P, Danko J. Different models of inheritance in selected genes in patients with sticky platelet syndrome and fetal loss. Semin Thromb Hemost 2015;41(03):330-335

69 Sokol J, Skerenova M, Jedinakova Z, et al. Progress in the understanding of sticky platelet syndrome. Semin Thromb Hemost 2017;43(01):8-13 